\title{
EML4 Gene
}

National Cancer Institute

\section{Source}

National Cancer Institute. EML4 Gene. NCI Thesaurus. Code C71003.

This gene may play a role in cytoskeletal assembly. 